\title{
DOING IT RIGHT: A RULE OF LAW CRITIQUE OF PRIVATIZATION METHODOLOGY IN NIGERIA
}

\author{
Sam Amadi*
}

\begin{abstract}
This article undertakes a rule of law critique of privatization as economic reform policy in Nigeria. The rule of law approach interrogates not just the policy rationales of the programme but also its methodology. The article distinguishes between a formal and substantive justice conception of rule of law and argues that the substantive justice conception of rule of law and its policy imperatives, sourced from the Fundamental Objectives and Directive Principles of State Policy in Chapter 2 of the 1999 Constitution, provides a veritable framework to realize the strategic goals of privatization in Nigeria.
\end{abstract}

Keywords: Privatization, rule of law, justice, efficiency, economic growth, equality, fundamental human rights, social justice.

DOI: https://dx.doi.org/10.4314/jsdlp.v10i1.4

\section{INTRODUCTION}

Privatization, as a governance framework, involves the transfer of ownership of stocks and assets from a nation to individual citizens or corporate entities. ${ }^{1}$ Since the 1970 s, privatization has been promoted across the world as a tool for dealing with public sector inefficiency and budget deficits. ${ }^{2}$ The real impetus for privatization, especially for many of the developing countries, arose from the global financial crisis that attended the Israeli-Arab war in 1973. This slowed down oil supply

* LLB (Calabar), BL, LLM, MPA, SJD (Harvard), Senior Lecturer, Faculty of Law, Baze University, Abuja. Email: samadi29@yahoo.com

1 Paul Starr, "The Meaning of Privatization" (1988) 6 Yale Law and Policy Review 6-41. Savas defines privatization as "the act of reducing the role of government, or increasing the role of the private sector, in an activity or in the ownership of assets." Also, Emanuel Savas, Privatization: The Key to Better Government (Chatham, NJ: Chatham House Publishers, 1987) 3.

2 Savas, ibid. 
and resulted in a balance of payment crisis for some commodity economies like Nigeria. But the dynamics for a global resort to privatization came from the United Kingdom under the regime of Margaret Thatcher whose Tory government decided to deal with UK economic crisis by the political ideology of reducing the role of government through the economic policy of privatization. It started with the steel industry and got to electricity. Between 1979 and 1992, the Thatcher administration had privatized 39 UK companies, making it one of the largest privatization exercises. Before then, privatization already started in Chile but it did not have a global impact like that of the UK. In Chile, the government unbundled vertically integrated utilities and sold them to private firms. In the United States, the government took to liberalization and restructuring. ${ }^{3}$ But, invariably, the UK example of privatization proved compelling across the world because of its capacity to raise $£ 16.6$ billion. ${ }^{4}$ Nigeria followed the UK example in 2001 with its National Electric Power Policy (NEPP). ${ }^{5}$

However, after many years of privatization attempts in Nigeria, especially in the electricity sector, the results so far have been very disappointing. Ranging from corruption, lack of transparency, poor quality of service, lack of capacity and injudicious tariff increases, the sector has been assailed with crises which suggest that privatization has not justified its billing. For example, In November 2013 when power assets were handed over to successful private sector bidders, the average quantity of electricity supplied from the grid was about 3,400MW. About six years later, on the day that the Minister of Power presented his three-year scorecard, electricity generation had fallen to $2,039 \mathrm{MW}^{6}$

The many failures and challenges have led to critiques of both the theory and practice of privatization. ${ }^{7}$ Policymakers are also rethinking whether privatization is a wise policy in the present context of economic

3 David M. Newbery, Privatization, Restructuring, and Regulation of Network Utilities (The MIT Press, 1999), pp. 1-25.

4 Ibid 19.

5 See for more details of the policy, Federal Republic of Nigeria, National Electric Power Policy (NEPP), 2000.

6 https://www.vanguardngr.com/2019/04/economy-bleeds-as-powergeneration-drops-to-2039mw/

7 Editorial, Punch Newspaper, 1 November $2018<$ https://punchng.com/powerprivatisation-disco-owners-must-let-go/> accessed 8 December 2018. 
development in Nigeria. ${ }^{8}$ The debate about privatization throws up the challenge of determining whether it is the economic theory or policy assumption or even the execution strategy of privatization that is the problem. Legal theorists should not be left out of this debate as the legal framework of privatization is as important as its economic theory propositions.

As Nigeria looks towards private sector finances to achieve its strategic growth policies, privatization as a solution to the challenges of economic development in Nigeria will remain a contentious issue. ${ }^{9}$ From a rule of law perspective, the debate on privatization should not end at whether public enterprises should be privatized or not. ${ }^{10}$ A rule of law perspective on privatization is not exhausted by a debate whether a country like Nigeria facing economic distress should resort to divesting its public stock to private firms or continue to look for solutions within the framework of public ownership and control of enterprises. That is obviously an important debate; and it has been the favoured form of critique of privatization, especially by the organized labour in Nigeria. As important, and even, preeminent, as this sort of critique might be, a rule of law critique of privatization should extend to a critique of both the methodology and mechanism adopted for the privatization of state-owned enterprise and the political and economic impacts of such divestment. ${ }^{11}$

This article is divided into five sections. After this introduction, section 2 discusses the meaning of a rule of law approach to

8 Nigerian Govt. to review power sector privatization, Premium Times, 12 October 2018. <https://punchng.com/power-privatisation-disco-owners-must-let-go> accessed on 8 December 2018.

9 All economic reform policies since the Structural Adjustment Programme in the 1980s have focused on privatization as a strategic intervention to boost productivity. Although the current Economic Recovery and Growth Plan (ERGP) did not specifically mention privatization as a strategy to achieve economic growth and diversification, it focuses on private sector leadership in providing critical infrastructure. See Ministry of Budget \& National Planning, Economic Recovery \& Growth Plan 2017-2020 (Abuja 2017), p.13.

10 I will explain hereafter the conception of rule of law this paper relies on. But for a general discussion of rule of law and privatization in Nigeria, see use Chapter 4 of Sam Amadi, Privatization and Public Good: the Rule of Law Challenge (CPPR 2008) for a fuller discussion of different perspectives of the concept of the rule of law.

11 There has been little focus on the methodology of privatization in public literature of privatization. The assumption seems to be the privatization is a zero-sum game: we either do it or we don't. but it does matter a lot how we do it. 
privatization and where it matters for privatization. It argues that it matters because of the imperatives of equality and fairness. It matters also because failed privatization will undermine the prospect of economic and social welfare, which is an objective of a rule of law approach to economic management. section 3 examines the legal framework of privatization scheme in Nigeria, including the Constitution that articulates the fundamental objectives of state policy and the laws that control privatization transactions in Nigeria. The section concludes that the failure of the privatization laws to incorporate constitutional values of fairness and equality undermines the prospect of achieving its strategic objectives. Section 4 explores the fundamental values that should guide valuable and effective privatization in the form of an indepth analysis of section 16 of Chapter 2 of the Constitution. Section 5 of this article considers how the failure of the rule of law has affected privatization in Nigeria. Adopting the substantive justice conception of the rule of law, it argues that the privatization process did not comply with the four imperatives implicit in Chapter 2 of the Constitution. Section 6 is the conclusion.

\section{WHY DOES A RULE OF LAW CRITIQUE MATTER FOR PRIVATIZATION?}

The rule of law critique is based on a rule of law approach to understanding social phenomena. A rule of law approach is different from a legalistic approach. According to Judith Shklar, "Legalism is the ethical attitude that holds moral conduct to be a matter of rulefollowing, and moral relationships to consist of duties and rights determined by rules". ${ }^{12}$ Contrarily, a rule of law approach relates social activities to the ideals and morality embedded in the law. It is not just about "rule following" nut more about alignment with the principles and purposes of the law. As Ronald Dworkin would argue, a rule of approach approximates the manner in which judges consider legal problems. For them, the law doesn't just consist of rules, but also principles and moral ideals. ${ }^{13}$ So, a rule of law approach to privatization

12 Judith N. Shklar, Legalism: Law, Morals, and Political Trials (Harvard University Press, 1986), p. 1.

13 Ronald Dworkin, Taking Rights Seriously (Cambridge, Harvard University Press, 1978). 
advocates compliances with such principles as equality, fairness and social wellbeing. ${ }^{14}$

There are at least two main reasons why the rule of law (particularly, human rights and social justice) advocates should bother about how a nation privatizes its public enterprises and social services. As earlier noted, privatization involves the transfer of ownership of stocks and assets from the nation to individual citizens or corporate entities. Such transfer may result in unfair enrichment of a few citizens and the deprivation of many others. ${ }^{15}$ It may also result in the creation of a private monopoly that may further reduce access and enjoyment of essential social services by the poor. Some may argue that there is little wrong with the disparity of wealth amongst citizens as long as such wealth is not gotten by theft and fraud, although democracy is best sustained where there is general equality amongst citizens. As long as such disparity of wealth is a result of disparity of efforts or unequal application of brain and brawn by citizens, the democratic theory may tolerate it. ${ }^{16}$ But where such inequality is a result of allocating public resources to some citizens and not the others, that is, where inequality results in the exclusion of some from access to basic social and economic opportunities, then, such inequality is both iniquitous and intolerable. ${ }^{17}$

14 See Sam Amadi, "Rule of Law Approach to Regulating Electricity Supply in Nigeria" (2017) 8 (2) Afe Babalola University Journal of Sustainable Development Law and Policy, pp. 26-32.

15 Fairness in matters of distribution has been a matter of grave concern to legal theory and political philosophy. Utilitarianism, libertarianism and justice as fairness as political philosophies and legal theories have differed on what is fair and just in relation to income and wealth. For libertarians like Robert Nozick, all forms of distribution of wealth apart from the use of free market is violative of human freedom. See Anarchy, State and Utopia (New York 1974).

16 Political philosophers have had divergent reactions to the fact of inequality. Aristotle and Thomas Hobbes did not consider general equality an important ethical value; hence their theories did not presume on the primacy of equality in constructing a just society. See Aristotle, Politics, Book 3 page 78. But modern liberal philosophers like John Rawls and Ronald Dworkin place more emphasis on equality.

17 Inequality has remained a major concern of liberal theory. Right from Thomas Hobbes to John Rawls, liberal political theory has grappled with how to justify inequality in the context of a just and democratic society. Hobbes thinks that as long as no human being is so powerful that he or she cannot be defeated by the combination of power and guile of other humans, then there is desirable equality (see Thomas Hobbes, Leviathan, ch. XIII). John Rawls accepts inequality only if it pertains to offices open to all citizens and if it is to the greatest advantage of 
Ronald Dworkin has tackled the problem of equality in an authoritative book. ${ }^{18}$ In his view, equality matters because it is at the heart of political morality and social justice for "no government is legitimate that does not show concern for all those citizens over whom it claims dominion and from whom it claims allegiance". Asking what needs to be equalized, he answered by rating the "equality of resources" above the "equality of welfare". ${ }^{19}$ But, the key point for this discussion is the recognition of the role of law and legal interventions in private and public markets in engendering equality and inequality. As Dworkin puts it, the distribution of wealth "is the product of a legal order: a citizen's wealth massively depends on which law his community has enacted - not only in laws governing ownership, theft, contract, tort, but its welfare law; tax law, labo[u]r law, civil rights law, environmental regulation law, and laws of practically everything else". ${ }^{20}$ In other words, inequality is not a natural result. It is socially constructed through legal intervention in socially autonomous and non-autonomous interactions. Therefore, where government intervention in an existing market results in inequality of income, then that intervention requires some justification as a legitimate act of government. For this reason, at least, legal theorists and social justice activists should care about the rule of law implications of privatization.

The second reason why rule of law and social justice theorists should care about privatization concerns the economic argument for privatization. Privatization ought to result in more productivity and greater efficiency in the use of scarce human and physical capital. If by virtue of the faulty mechanism of privatization, efficiency or productivity is endangered, the material welfare of citizens is underserved. Since rule of law includes the promotion of social and welfare development of people on the one hand, and the Nigerian Constitution commits the state to securing the welfare of Nigeria on the other, a privatization process that fails to engender efficiency and productivity does not promote the rule of law. So, it is in the interest of the promotion of human rights and the protection of the rule of law that we continue to

the least advantaged members of the community (See Rawls, Political Liberalism (Columbia University Press 1996).

18 Ronald Dworkin, Sovereign Virtue: The Theory and Practice of Equality (Cambridge Mass. 2000).

19 Ibid.

20 Ibid., p. 1. 
inquire about the methods and approaches that the privatization agency adopts to deal with inefficient public enterprises and institutions. The logic of privatization is partly that the monopoly status of public enterprises more or less disposes them to inefficiency in utilization of resources which invariably results in welfare loss for citizens as consumers. ${ }^{21}$ Therefore, allowing monopolistic structures around private ownership may lead to a similar welfare loss.

Since the late 1980s, and arising partly because of the Structural Adjustment Programme (SAP) introduced to address the balance of trade deficits of Nigeria and other Sub-Saharan African countries, privatization has featured prominently as a policy to reform the economy. ${ }^{22}$ The National Economic and Empowerment Development Strategy (NEEDS) arguably has been the boldest and most comprehensive of Nigeria's economic reform plan since $2000 .{ }^{23}$ NEEDS states that "the government will ... privatize, deregulate and liberalize publicly owned industries to promote competition, expand industries, generate employment, create wealth, and receive value for money". But, NEEDS does not provide any guidance on how to privatize public enterprises. It seems to argue that privatization howsoever conducted would be beneficial to the Nigerian economy. But, as Nobel Laureate Joseph Stiglitz famously puts it, privatization, even if it is a good policy, can be wrongly executed. And when it is executed in a wrong manner, the consequence is not just that the efficiency gain is lost, but a lot more harm can be done to citizens, especially the poor. ${ }^{24}$ The most important and enduring problem of privatization in Nigeria may not be the rationale for its introduction. It would rather be the ill-conceived and poorly executed processes and mechanisms that have resulted in faulty privatization. This article considers the rule of law framework of a welfare-enhancing privatization in Nigeria and what fundamental criteria needs to be met before such privatization could be rule-of-law compliant.

21 See Chapter 1 of Bernardo Bortolotti and Domenico Siniscalco, The Challenge of Privatization: An International Analysis (Oxford University Press 2004) for a discussion of the economic theory underlining privatization.

22 Sam Amadi, Privatization \& Public Good: The Rule of Law Challenge (CPPR 2009), p. 35-45.

23 National Planning Commission, Meeting Everyone's Needs: National Empowerment and Economic Development Strategy (NEEDS) (Abuja: National Planning Commission, 2004).

24 Joseph Stiglitz, Globalization and its Discontents (WW Norton 2003), pp. 54-58. 


\section{ANALYSIS OF THE LEGAL FRAMEWORKS FOR PRIVATIZATION IN NIGERIA}

Privatization has been conducted under a plethora of laws that often seem inconsistent or incoherent when compared with the Constitution. Most of these sector laws regulating privatization exercises in Nigeria were enacted under military rule. Under the military, some of the provisions of the Constitution are either suspended or amended or the entire extent of constitutionalism severely limited, ${ }^{25}$ therefore, these privatization laws may not embody some of the rule of law values embedded in the Constitution. There are two basic laws governing the privatization of public enterprises in Nigeria: the Constitution and the privatization laws, particularly the Public Enterprises (Privatization and Commercialization) Act 1999.

\subsection{Constitutional Framework}

The 1999 Constitution provides the basic rule of law framework for any economic or commercial activity in Nigeria. It empowers the President, by himself or through the ministers or other assistants, to manage the national economy for the good of the Federal Republic of Nigeria. ${ }^{26}$ The Constitution grants the National Assembly the power of

25 The military government usually suspended the Constitution whenever it took over power from civilian government. It achieved this by enacting a Constitution modification and suspension decrees. These decrees suspend the legislative branch of government and modify the provisions relating to the jurisdiction of the court and enforcement of fundamental rights of citizens. See the Constitution (Suspension and Modification) Decree No.1 of 1984 (particularly, sections1-5) and The Federal Military Government (Supremacy of Powers) Decree No. 13 of 1984. The Supreme Court approved these restrictions in F.S. Uwaifo v. Attorney General of Bendel State (1982) SC. The Supreme Court nailed it per KaribiWhyte, JSC in Military Government of Ondo $v$. Adewunmi (1988) 3 NWLR (Pt. 82) 208 at 305 that "The Constitution, in so far as it survived and it applied, did and still does so on the benevolence, sufferance and behest of the authority of the Military Government". See generally Ben O. Nwabueze, Military Rule and Constitutionalism (Spectrum Books, 1992), pp. 20-21.

26 Section 5(1)(a) of the CFRN, 1999 provides that “...the executive powers of the Federation shall be vested in the President and may, subject as aforesaid and to the provisions off any law made by the National Assembly, be exercised by him either directly or through the Vice President or Ministers of Government of the Federation or other officers of the public service of the Federation...”. This is the foundation of the President's power to manage the national economy. 
co-managing the economy through legislation and policy oversight. ${ }^{27}$ The Constitution also provides a full complement of "fundamental human rights" which every public official and institution should observe, at the risk of judicial sanctions. ${ }^{28}$ These rights, which can be adjudicated in a court and remedies granted by courts are coupled with other "social and economic rights" which are deemed unenforceable by the courts. The second category of "rights" is described as the "Fundamental Objectives and Directive Principles of State Policy". ${ }^{29}$ These directive principles arguably provide the economic, social and cultural objectives for the management of natural and physical resources and assets in Nigeria. They also provide for both the strategic and normative directions of economic development and the social and political welfare of Nigerian citizens.

It is pertinent to analyse some of the provisions of the "Fundamental Objectives and Directive Principles of State Policy" in order to illustrate the strategic and normative definitions of statecraft in Nigeria and provide a good framework for a rule of law critique of the privatization methodology. The relevant provisions are in section 16 of the Constitution, which defines the economic objectives of the Nigerian government as follows:

The State shall, within the context of the ideals and objectives for which provisions are made in this Constitution - (a) harness the resources of the nation and promote national prosperity and an efficient, a dynamic and self-reliant economy (sic); (b) control the national economy in such a manner as to secure the maximum welfare, freedom and happiness of every citizen on the basis of social justice and equality of status and opportunity; (c) without prejudice to its right to operate or participate in areas of the economy, other than the major sectors of the economy, manage and operate the major sectors of the economy. ${ }^{30}$

First, the Constitution commits the government to ensuring a prosperous and efficient economy that is dynamic and self-reliant. It

27 See sections 80-88 of the CFRN 1999.

28 See Chapter 4 of the CFRN, 1999 guaranteeing classical form of civil and political rights.

29 See Chapter 2 of the CFRN 1999 guaranteeing social, economic and cultural rights.

30 Ibid. 
assumes that "prosperity" "efficiency" and "self-reliance" are complementary virtues and their actualization are self-reinforcing. That is, an efficient economy will be prosperous as well as self-reliant. So, at the minimum, the management of the national economy must have as its declared objective a clear commitment to wealth creation and maximizing collective wealth. This can be called "the growth imperative" of the national economy. The second aspect of section 16 relates to a commitment to ensure that the management of the national economy leads to social justice and equity. The Constitution proclaims the equality of status and opportunity to access the basic structure of justice - what in the language of modern liberalism is called "basic social goods" or "basic structure of justice". ${ }^{31}$ This second commitment is called "the social justice imperative" of the national economy. What I call "the social justice imperative" is based on the concept of equality or equal regard. The sort of equality envisaged in the directive principle of state policy is one that provides equal opportunity for all citizens to "maximize welfare, freedom and happiness". This is a form of egalitarianism or prioritarianism. ${ }^{32}$ We will say more about this when we discuss further on the fundamental values underwriting these imperatives.

The two imperatives are further reinforced by another imperative: "the state regulatory imperative", which requires that no matter the mode of production adopted for the management of the major sectors of the economy, the state must continue to exercise its regulatory powers to ensure protection of all the citizen to engage in meaningful economic activities. This imperative comes out clearly in section 16 (1) (d). It also empowers Nigerians to engage in other sectors of the economy outside the major sector the economy. Therefore, it mandates free enterprises in addition to the maintenance of public enterprises. So, no law should deprive Nigerians of the right to engage in profitmaking enterprises.

31 See John Rawls. A Theory of Justice (Cambridge, MA Harvard University Press, 1971); John Rawls, Political Liberalism (Columbia University, 1993), especially Lecture VII.

32 "Prioritarianism maintains that a greater weight should be placed on improving the well-being of those who are worse off than on improving the well-being of those who are better off. Prioritarians, like egalitarians, will in practice endorse policies that reduce inequality". See Daniel Hausman, Michael McPherson and Debra Satz, Economic Analysis, Moral Philosophy and Public Policy (Cambridge 2017), p. 202. 
Subsection 2 of section 16 further mandates the government to manage the economy in a manner that ensures a "balanced and planned" economy in which its material benefits are shared in a manner that promotes "the common good", and ownership and control of the means of production and distribution is not concentrated in the hands of a few. This implies a fourth imperative: "the imperative of equality". Subsection 3 goes further to prescribe that the legislature will establish an agency to monitor and review the ownership structure of the Nigerian economy and would recommend to the President an industrial structure as well as implement any law on enterprise ownership and control. We can describe this as "the imperative of a planned economy". Subsection 4 defines "major sector of the economy" to mean a sector so declared by the National Assembly and guarantees that unless a contrary resolution is issued by the National Assembly, any sector exclusively managed by the government either directly or through a corporation or agency, shall not be open to private participation. This is "the imperative of public enterprise". I will discuss these imperatives in the context of the normative landscape of the privatization exercise in Nigeria when we analyse the value orientation of the programme. In the meantime, it is pertinent to analyse the transactional laws guiding the privatization programme to see how they align with the constitutional provisions.

\subsection{Legal Framework}

The initial framework for privatization in Nigeria was established during the military administration of General Ibrahim Babangida. The military government of Ibrahim Babangida introduced the privatization programme in Nigeria as a conditionality for the IMF economic reform programme during the global financial crisis of the late 1980s. ${ }^{33}$ This set of fiscal policy responses (the harbinger of the Washington Consensus) is generally called the Structural Adjustment Programme. ${ }^{34}$

33 As part of the politics of the Structural Adjustment Programme, the Babangida administration orchestrated a public debate on the acceptability of the International Monetary Fund's (IMF) loan and its conditions. Although the Nigerian people overwhelmingly rejected the loan, the administration nevertheless implemented the condition, which included the withdrawal of government from the "commanding heights of the economy".

34 See John Williamson, "What Washington Means by Policy Reform" in John Williamson, ed., Latin American Adjustment: How Much Has Happened? 
The first set of privatization was executed under the Privatization and Commercialization Act of $1988 .{ }^{35}$ In 1993, the government established the Technical Committee for Privatization and Commercialization (TCPC) pursuant to powers under the 1988 Act. ${ }^{36}$ The TCPC recommended the speeding up of the privatization programme. Later, another law, the Bureau for Public Enterprises law created the Bureau for Public Enterprises (BPE) to replace the TCPC, take over the process and continue the privatization programme. ${ }^{37}$ In 1999, the Federal Government repealed the BPE Act and enacted the Public Enterprises (Privatization and Commercialization) Act 1999. ${ }^{38}$ The new Act created the National Council on Privatization as the policymaking authority on privatization and the Bureau for Public Enterprises (BPE) as the transaction manager of privatization. ${ }^{39}$ The Vice-President is the chairman of the Council. ${ }^{40}$ The 1999 Act attempts to streamline the bureaucracy of privatization in Nigeria in such a way that "steering" is sequestered from "rowing". Whereas the National Council on Privatization (NCP) determines broad privatization policies (steering), the Bureau for Public Enterprises (BPE) executes the technical tasks of privatizing designated public enterprises (rowing). The Council is vested with far-reaching powers and has the BPE as its secretariat.

The applicable law for privatization in Nigeria today is the Public Enterprises (Privatization and Commercialization) Act 1999. The other laws have been repealed. This law does not provide the strategic objectives and guiding principles for privatization. It only provides that the National Council on Privatization has the authority to determine "the political, economic and social objectives of privatization and commercialization in Nigeria". ${ }^{41}$ The Act also provides for two basic modes of divestment of government shares in public enterprises to be privatized. this could be by public issue or private placement.

(Washington DC, Institute of International Economy 1990) for a discussion of the series of policy choices referred to as the "Washington Consensus".

35 Privatisation and Commercialisation Act No. 25 of 1988.

36 Ibid.

37 Bureau for Public Enterprises Decree No. 28 of 1993.

38 Public Enterprises (Privatization and Commercialization) Act, 1999 Cap 38 Laws of the Federation of Nigeria.

39 Section 8 of Public Enterprises (Privatization and Commercilization) Act 1999.

40 Other members of the Council include the relevant Ministers of Finance, Justice, Industry, and the Governor of the Central Bank of Nigeria.

41 Section 11, ibid. 
Nevertheless, the act gave the NCP power to determine the mode to be adopted for any specific privatization, including by willing buyer or willing seller mode. ${ }^{42}$

It is remarkable that the privatization process in Nigeria started with clear national legislation. Privatization does not require a comprehensive legislation as such. But the reason for this demanding legislation might be because the constitutional and legal designation of some enterprises in Nigeria as public enterprises necessitated the need for a comprehensive national privatization law. Not doing so would have enabled a disaffected person or even the leadership of organized labour to seek judicial invalidation of the entire privatization programme. Again, a comprehensive legislation could notionally engender transparency and accountability, and therefore, militate against populist opposition to the process that may result in a policy reversal. But beyond the formal notion of transparency and accountability that a national legislation may provide, the question that should interest critical observers is whether the structures and agencies established under the law are able to promote accountability and efficiency in reality. Furthermore, it is important to ask whether the privatization programme itself is being executed according to the provisions of the law?

The first comprehensive economic reform programme after the enactment of the 1999 Constitution was the National Economic Empowerment and Development Strategy. The NEEDS document did not create a new privatization law; instead, it acknowledged the existing one. NEEDS renewed privatization initiatives were constructed under the legal regime established by the Public Enterprises (Privatization and Commercialization) Act. Under this regime, the National Council on Privatization has responsibility for formulating broad policies on privatization for the Bureau for Public Enterprises to execute. The Council is made up of government officials, including the AttorneyGeneral of the Federation, the Minister of Finance, and the Governor of the Central Bank. The Chairman of the Council is the Vice-President. The relationship between the NCP, the BPE and the ministries with managerial responsibility for the enterprises slated for privatization is neither clear nor coherent in the law. This incoherence affects the quality of privatization deals. Such was evident in the controversy over the

42 Section 2, ibid. 
privatization of the nation's only airline, the Nigerian Airways. The Minister of Aviation and the Director-General of the BPE disagreed on the suitability of the core investor - Airwing of UK - to turn-around the aviation industry.

The NCP was invested with power to, among other things, determine the political, economic and social objectives of privatization; designate the public enterprises to be fully or partially privatized or commercialized; approve the legal and regulatory framework for the privatization; and review periodically the impacts and effects of privatization. BPE had the mandate to implement NCP's policies on privatization and commercialization; prepare enterprises for privatization and commercialization and advise the NCP on which enterprises to privatize and the methods to adopt. The law also designated enterprises to be fully or partially privatized or commercialized. Enterprises to be partially privatized included the Nigerian Telecommunications Ltd (later Plc); National Electric Power Authority; Daily Times of Nigeria; New Nigeria Newspapers; NICON Insurance Company; Nigerian Airways Ltd; and so on. Enterprises to be fully privatized included FESTAC 77 Hotel; African Petroleum; Unipetrol; ANAMCO; VON; West Africa Cement Co, and so on. Enterprises to be partially commercialized included Nigeria Railways Corporation; Nigeria Television Authority; Federal Radio Corporation of Nigeria; etc, while Nigerian National Petroleum Corporation; Nigeria Ports Authority; Federal Housing Authority; etc, were to be fully commercialized. The law authorized the NCP to re-designate an enterprise from one category to another as it deemed fit. Critics have interpreted this provision as contravening the Constitution that grants the National Assembly the exclusive power to amend legislation. To grant an agency or executive body power to re-designate enterprises that the parliament had previously designated for a particular purpose is to grant such agency or body the power to make laws. ${ }^{43}$ But, clearly, the National Assembly has delegated the power to relist enterprises to the NCP.

43 Kalu Onuoha, "The Legal Regulation of Privatization - A Critique" and Emeka Iheme, "The Legal Regulation of Privatization in Nigeria" in Eze Onyekpere (ed.) Readings on Privatization (Socio-Economic Rights Initiatives 2003) for arguments in support of the claim of unconstitutionality of the section 6 (3) Act 28 of 1999 which purports to authorise the NCP to re-designate enterprises for privatization of commercialization. 
The faulty legal regime of privatization and the initial lack of legal incidences of privatization knowledge on the part of transaction managers led to many avoidable policy errors which distorted the process, entrenched inefficiency and engendered public scepticism. The BPE failed to do a proper legal audit before proceeding with the privatization of some enterprises. The case of NEPA stands out. For instance, BPE prepared NEPA for privatization even after the NEPA Act had described it as a public enterprise and granted it exclusive right to produce and market electricity in Nigeria. BPE thus proceeded on the erroneous assumption that it could privatize NEPA without a specific enabling legislation until the House of Representatives Committee on Privatization overruled it. ${ }^{44}$

Privatization advocates argue that it is always better to lock the privatization process into a duly enacted law, saying it would increase the cost of revision and reversion. This is because policies change faster than legislation, and when a process is locked into legislation, interests built upon it are better protected against the risks of democratic politics. This is a form of political insurance. Legislation will also assure the investors that the rules and processes that will determine their fate are not amenable to executive fiat or administrative neurosis. Investors prefer great clarity in terms of risks and benefits. They understand that process is very important; hence they demand clear and prior rules of engagement that stipulate rate making and other incidences of profitability and sustainability of their business. This is an aspect of the formalistic conception of the rule of law which has featured greatly in the rule of law mantra that institutions such as the World Bank bandy around as being among the important criteria for economic development. Such conception was unhelpful, as David Trubek argues, because it did not "include protection of human rights but . . . included the right to property as well as civil and political rights. Property was emphasized. The role of the judiciary was to police the boundaries between state and market, and it was thought they would do this through a formalistic mechanism". ${ }^{45}$ Even the formalistic conception

44 Ibid and see also Sam Amadi, Privatization \& Public Good (supra), pp. 143155.

45 David Trubek, "The Rule of Law in Development Assistance: Past, Present, and Future" in David Trubek and Alvaro Santos (eds), The New Law and Economic Development: A Critical Appraisal (Cambridge 2006), p. 87. 
of rule of law as clarity and certainty cannot be achieved by only enacting one transaction law. There is a need to have other laws dealing with accounting, bankruptcy and, most importantly, competition. Failure to have such supplementary legislation means there is incomplete legalization of privatization procedures, which could lead to a failed privatization.

Privatization is not a stand-alone in the quest for efficiency and quality of service post-privatization. This will require the full complement of institutions that incentivize efficient behaviour and create the environment for an orderly running of the market. If the inefficiency of the public enterprise is traced mainly to the principal-agent problem and the prevalence of "soft budget line", then successful privatization would require institutionalization of corporate governance rules that commit agent to pursue principal's interests and impose hard budget lines on the entity. This is achieved through comprehensive and effective legislation. The assumption that privatizing public enterprises necessarily cures these corporate pathologies is false, as demonstrated by Adam Przeworski et al. As they rightly argue, the assumption that public enterprise is rife with the principal-agent problem and private enterprises free of it is false. What saves the private or public enterprise from the principal-agent problem and the perverse incentive of "soft budget line" is good corporate governance regime and not necessarily change of ownership. ${ }^{46}$

If the end of privatization is to improve service delivery to citizens as consumers, then the exercise ought to proceed with the end in mind. This means that the design and execution of privatization should be based on how the enterprise will perform differently, how this performance will affect the industry and how the industry performance will affect the general economy. So, it should be a predictable movement from allocative efficiency to dynamic efficiency. This calls for legislative and regulatory audit to ensure that every stage of the process complies with both the enabling law as well as achieve the strategic objectives of privatization, including the constitutional imperatives. These strategic objectives should be part of the complementary legislation that supports privatization and constitutes the new political economy

46 Adam Przeworski, "Privatization and its Alternatives" in Adam Przeworski et al, Sustainable Development (Cambridge 1995), p. 94. 
of efficient and competitive operations. This new emergent legal regime should include competition policy and framework articulated in antitrust legislation. ${ }^{47}$

Successful privatization will also require that at each stage of the process, the transaction managers conduct due diligence on the legal status of enterprises to be privatized so as know what sort of ownership and management structure the law has stipulated for the enterprise and determine whether it is necessary to re-designate such enterprise before privatization. This is one aspect of the formalist compliance with rule of law. In some instances, the transaction managers had claimed to have privatized such designated enterprises without changing their legal designation. That was what happened in the botched privatization of the railways, which the legislature cancelled because of failure to follow the law. ${ }^{48}$

The lack of detailed provision on the strategic objectives and normative framework for conducting privatization in the transaction law means that a greater than necessary discretion is granted to the National Council on Privatization to determine the entire methodology of privatization through the Bureau of Public Enterprises. This legislative lacuna has disposed privatization manager to betray a lack of commitment to the four imperatives established in section 16 of the Constitution. The legal regime for privatization in Nigeria fails to incorporate the rule of law values which the Constitution has mandated as part of the directive principle for the management of the national economy. I argue that this avoidance or neglect has contributed to making privatization in Nigeria unable to achieve results that conform to the rule of law. Therefore, the lack of legislative clarity and comprehensiveness may have resulted in the rule of law deficiency in Nigeria's privatization.

47 Many years after beginning privatization, Nigeria is yet to enact a competition law. A competition bill has failed twice in the National Assembly. The latest one - Federal Competition and Consumer Protection Commission Bill - is has just been passed by both houses of the National Assembly and sent to the President for assent. The author was chairman of the Senate Technical Committee that reviewed the proposed bill before its passage.

48 Punch Editorial 27 July 2005. 


\section{WHICH FUNDAMENTAL PRINCIPLES AND VALUES SHOULD GUIDE PRIVATIZATION PROCESS?}

Does the Constitution support the divestment of government shares in public enterprises to private firms? Does section 16 of the Constitution mandate that the main sector of the Nigerian economy should be under public ownership and control? Or does it authorize private ownership and control of these main sectors of the economy? As clear as this constitutional provision may seem, it doesn't provide a clear and unambiguous answer to these questions. This constitutional provision lends itself to conflicting interpretations. Critics of privatization can and have relied on this same section 16 of the Constitution to argue against the privatization of public enterprises. ${ }^{49}$ The idea that the "commanding heights of the economy" should remain under the control of the public sector is popular with some radical economists and their civil society supporters. The history of public ownership and management of utility services in Nigeria takes a different path from those of Britain or the United States. In both countries, utility services started as private enterprises before the economies of scale and failure of regulation encouraged municipal takeover as public monopolies. ${ }^{50}$ On the other hand, because Nigeria became independent during a period marked by the triumphant move of socialism and nationalization in newly decolonizing countries, Nigeria began with the government controlling an overwhelming percentage of economic activities. Although the country is a mixed economy, the government still controls important sectors like power, oil and gas, telecommunications and transportation. Often it manages these economic activities through a public corporation or joint ventures where it exercises ownership rights. This history and context support the interpretation

49 For years, the Nigerian Labour Congress and its affiliate organizations of the working-class people have consistently challenged the privatization exercise in Nigeria. Part of their grouse is that the transfer of public wealth to private firms is unconstitutional. See Ayo Ayodeji, "Oppose The Privatization and Liquidation of PHCN" < http://www.workersalternative.com/national-issues/123-aa > accessed 7 November 2018.

50 David M. Newberry, Privatization, Restructuring, and Regulation of Network Utilities (Cambridge, Mass. 1999). See chapter 6 of Jose' A. Gomes-Ibanez, Regulating Infrastructure: Monopoly, Contracts, and Discretion (Harvard 2003) for a comparative analysis of the rise of public utilities in the US, Canada and Latin America. 
of section 16 of the Constitution which mandates public ownership of the "commanding heights of the economy".

But the same provisions can be read to mean that the Nigerian Constitution permits, and even requires, private ownership of major economic activities. This reading of the Constitution argues that any citizen or group of citizens (including corporate citizens) can operate any business in Nigeria, including those economic activities that may be deemed to fall under the "commanding heights" of the economy unless such a sector has been restricted by a resolution of each House of the National Assembly to be operated exclusively by the Government of the Federation. Therefore, it suffices to say that any governmentowned business can be operated by every Nigerian so long as it has not been declared a "major sector of the economy". A few businesses have been classified under "major sector of the economy" through laws that established public monopolies to manage them. An example was the National Electric Power Authority (NEPA) which had exclusive power to generate and market electricity in Nigeria before the present wave of privatization. ${ }^{51}$

In privatizing public enterprises, therefore, government has often failed to pay attention to the implications of constitutional provisions. Despite the preferred reading of section 16 of the Constitution and the preferred side on the debate over public/private ownership of the commanding heights of the economy, it is clear that in translating from public to private ownership, the state should protect and promote some constitutional values. For example, it must ensure that privatization results in efficient utilization of resources. In this sense, enterprises should not function less efficiently after privatization. And they should not create social costs that outweigh their economic gains. ${ }^{52}$

The Constitution also requires enterprises to be run in a manner that guarantees a self-reliant economy. It is difficult to say what is a self-reliant economy in an age where openness and global integration have been accepted to be the norm. Does it mean an economy where

51 Section 1 of the National Electric Power Authority Act, Chapter 256, Laws of the Federation of Nigeria,2000. This law has been repealed by the Electric Power Sector Reform Act, 2005.

52 This will surely be a controversial view. Many will believe that the proper focus should be on economic costs and benefits, not on social costs and benefits such that where the privatized company performs more efficiently as a result of privatization, social costs should be disregarded. 
the major enterprises are owned by citizens as was the case in Nigeria before economic liberalization? Or is it an economy that is cleverly insulated against the manipulation of external economic actors and the exogenous crisis of international capitalism? In the present context of global trade openness and intense networking of world economies, a constitutional requirement of economic self-reliance stipulates, at least in the minimum, an economy that is not so import-dependent and externally-oriented that it compromises the welfare of the citizens by making goods and services relatively dearer for them. An economy will not be self-reliant if local factors of production, including human capital, are not developed and made competitive, thus forcing them to rely on technical expertise and financial capital from overseas to run the economy. ${ }^{53}$ Whether the goal of self-reliance is a priority for an economy like Nigeria's is questionable. The premise for it, however, is the need to guarantee sustainable economic welfare for the citizens, especially in the era of western imperialism and Cold War rivalry which treated developing countries as pawns.

The Constitution also imposes the objective of fairness and equity on the management of the national economy. The government is required to manage the economy in a manner that "secures the maximum welfare, freedom and happiness of every citizen on the basis of social justice and equality of status and opportunity". Nigerian constitutional jurisprudence does not shed much light on the exact intent of the framers of the Constitution. ${ }^{54}$ Does the Constitution intend

53 There is a debate whether a country that has signed up to the "Washington Consensus", including privatization and liberalization, has a choice on the direction of its economy. Thomas Friedman has argued that once a country puts on the "straightjacket" it loses the autonomy to determine its economic fate (Friedman, The Lexus and the Olive Tree: Understanding Globalization (Picador 2012). Joe Studwell, How Asia Works: Success and Failure in the World's Most Dynamic Region (Grove Press 2013) argues that East Asia prospered by deviating from the official script of the Washington Consensus.

54 Most judicial interpretations of constitutional provisions have not been consciously based on legislative history, especially proceedings of constitutional conference. Nigerian judges have been more inclined to adopting a strict constructionist approach that relies on the clear meaning of the text. Nigerian judges have been more textualists and when they have been more activist in their interpretation it has not been based on deliberate resort to deliberative materials in the parliament. In Nafisu Rabiu v. The State (1980) 2 NCLR 293, Udo Udoma, JSC, offered a classical expression of the broad approach to constitutional interpretation in Nigeria, to wit, that the broad meaning should 
a welfarist, capitalist, or socialist economy? What notion of "social justice" and "equality" did they have in mind? Is it equality of resources or equality of opportunity? 55

These questions will require extensive clarification and study. However, what is remarkable is the failure of the privatization agency to conceptualize and justify the rationale and expected benefits of privatization according to the schema of interests and values that the Constitution has mandated. ${ }^{56}$ This failure may relate to a perverse legalism that capitalizes on the statement in the Constitution that the judicial power of the court to determine questions of violation or deprivation of rights and interests shall not extend to the "question as to whether any act or omission by any authority or person or as to whether any law or any judicial decision is in conformity with the Fundamental Objective and Directive Principles of State Policy". ${ }^{57}$ This provision in the country has been adjudged by the Supreme Court as precluding judicial enforcement of provisions of the Directive Principle except they have been further legislated into law. ${ }^{58}$ The disavowal of judicial enforcement has induced a thinking that there is no legislative and executive obligation to implement these directives in spite of the clear prescription in section 13 that all authorities and persons must apply the directive principle. ${ }^{59}$ This is a wrong reading of Chapter 2 of the Constitution and the decisions of the court of its judicial enforcement. These cases have not tried to reconcile the clear and mandatory language of section 13 and the exclusory language of section 6(6)(c). Although the Nigerian Supreme Court has always urged for expansive interpretation in the interpretation of the constitutional text,

be preferred to the narrow in constitutional interpretation except there is something in the instant case to make the narrow meaning preferable.

55 See Ronald Dworkin, Sovereign Virtue; The Theory and Practice of Equality (Cambridge MA, Harvard University Press, 2002) for a discussion of different conceptions of equality.

56 The Bureau for Public Enterprises (BPE), the transactions manager, has always justified privatization exercises on the basis of their legality and due process and not on the basis of following imperatives in section 16 of the Constitution.

57 Section 6(6) (c) of CFRN 1999.

58 A.G. Ondo v. A.G. Federation \& 35 Ors. (2002) NWLR (Pt. 722) 222

59 Section 13 CFRN 1999 states, "It shall be the duty and responsibility of all organs of government and of all authorities and persons, executive, legislative or judicial powers to conform to, observe and apply the provisions of this Chapter of this Constitution". 
it has ill-advisedly limited the enforceability of the Directive Principles of State Policy.

One explanation for the hesitation to accord the rights in Chapter 2 equal status with Chapter 4 rights might be that the protection of Chapter 2 rights requires heavy public budget and policy implementation whereas Chapter 4 rights are self-executory. This is the so-called dichotomy between "negative" and "positive" rights. But, like Stephen Holmes and Cass Sunstein argue, this distinction is arbitrary. "Rights are costly because remedies are expensive. Enforcement is expensive, especially fair and uniform enforcement, and legal rights remain hollow to the extent that they remain unenforced. Formulated differently, almost every right implies a correlative duty, and duties are taken seriously only when dereliction is punished by the public purse drawing on the public purse". ${ }^{60}$

Some human rights groups oppose privatization on the ground that transferring public ownership of important economic activities to private firms violates the fundamental objectives and directive principles of state policy, even if the court will not grant remedial orders. ${ }^{61}$ Evidently, the jurisprudential basis of the contention that privatization of public enterprises in Nigeria is unconstitutional is weak, if we consider the stance of Nigerian judges on the enforceability of Chapter 2 rights. ${ }^{62}$ Textualism has been the dominant interpretive mode of Nigerian judges. This restricts the meaning and effect which the courts can give to the fundamental objectives. ${ }^{63}$ But, a more functional

60 Stephen Holmes and Cass R. Sunstein, The Cost of Rights: Why Liberty Depends on Taxes (New York 1999), p. 43.

61 Chom Bagu argues that privatization does not maximize the welfare of the people, rather it exposes Nigeria to the unseen market forces. Therefore, it is unconstitutional because the Constitution seeks to protect Nigerians from the repercussions of the volatility of the market. See Chom Bagu, "Efficient Allocation of Resource Or Looting the Patrimony: A Critical Review of Privatization in Nigeria" in Eze Onyekpere (ed.), Readings on Privatization (2003) SERI, pp. 47-8.

52 The Nigerian courts reacted quickly to the inclusion of social and economic rights in the Constitution and held that those rights under the Fundamental Objective and Directive Principles of State Policy are not enforceable. See Archbishop Okogie v. Attorney General of Lagos State (1981) 2 NCLR 337.

63 A good example of textualism leading to obnoxious outcome is the interpretation the Supreme Court gave to the power of the Attorney General to discontinue criminal proceedings in section 211 od CFRN 1999 in State v. Ilori (1983) 2 S.C. 155 Whereby the court clothed him with unreviewable discretion in matter of criminal prosecution. 
interpretive stance will consider that the Constitution mandates public officials to bear in mind these directive principles in managing national affairs. If public officials ought to reflect these fundamental objectives in the policies they design and how they manage these policies, why would a court not have the jurisdiction to, at least, review the effects public officials give to the objectives. Many human rights groups have initiated legal suits to challenge privatization for violating or depriving the state of resources to fulfil these fundamental principles. Most of these suits were non-suited by judges who refuse to exercise jurisdiction on the grouse that these objectives are not enforceable. ${ }^{64}$

The Nigerian Constitution rightly contains chapter 2 rights because of their importance to both advancing individual welfare and ensuring sustainable economic and social development. The court's restrictive and formalistic interpretation of sections 6 and 13 of the Constitution frustrates the objective of the Constitution which is to "promote the good government and welfare of all persons in our country, on the principles of freedom, equality and justice". ${ }^{65}$ By placing a "duty" upon every public official to comply with the provisions of chapter 2 the framers of the Constitution understand that unless certain immediate economic and social goals are made immediately attainable, non-violent social change may be impossible. Thus, by making those social and economic goals immediately attainable, chapter 2 makes "welfare state attainable". ${ }^{66}$ Employing a Hohfeldian analysis, ${ }^{67}$ Justice Oputa argues that section 13 makes Chapter 2 rights enforceable because "duty is the correlate of right and is to be applied to those acts which a person is bound to do by virtue of the office he holds". ${ }^{68}$ Criticizing Nigeria's jurisprudence on the enforceability of social and economic rights, Oputa urged the courts to adopt the prudential jurisprudence of the India

64 N.U.E.E. v. BPE (2010) 7 NWLR (Pt. 1194), p. 583.

65 Preamble to the Constitution of the Federal Republic of Nigeria, 1999.

66 C.A. Oputa, Themes on Judicial Activism and the Law (Abuja 2014), p. 100.

67 American legal theorist, Wesley Hohfeld attempted to clarify the language of "rights" by aligning legal pedagogy to legal philosophy. He posited four usages of "right" in the form of jural correlates and jural opposites. His important contribution is the insight that the use of "right" as claim imports "duty" as a correlate. See Wesley Hohfeld, "Some Fundamental Legal Conceptions as Applied in Judicial Reasoning", 23 Yale Law Journal 16 (1913) and "Fundamental Legal Conceptions as Applied in Judicial Reasoning”, p. 26 Yale Law Journal 710 (1917).

68 Ibid, page 99. 
Supreme Court which considered judicial enforcement of Directive Principles of State Policy in the Indian Constitution critical to the achievement of the constitutional prescription of a welfare state. ${ }^{69}$

But, in spite of the jurisprudence of their judicial enforceability, these objectives are important as tools of public policy analysis and management. The court agrees that not being justiciable does not mean these directives are not important and could not be realized through policy or programme. ${ }^{70}$ Privatization, being a programme to improve the economic and social well-being of the citizens and residents in Nigeria, should be benchmarked on how it helps to realize the fundamental objectives of efficient utilization of natural resources and promote a self-reliant economy, equity, and social justice across ethnic, gender and class groups. The fact that a privatization process flouts fundamental constitutional objectives (whether they are strictly enforceable or not) goes to demonstrate its incoherence and illegitimacy; and further makes it unpopular and unsustainable. Above all, such failure to comply with these constitutional directives (justiciable or not) shows that privatization, as an exercise, rather than as a policy choice, flouts the test of compliance with the rule of law. As indicated hereunder, failure to conform to the rule of law imperatives in the Constitution makes the privatization process fraught with legal, political and technical errors which compromise the postprivatization performance of the enterprises and the political sustainability of privatization itself.

\section{RULE OF LAW FAILURE AND THE FAILURE OF PRIVATIZATIONS}

The rule of law critique in this article has taken two dimensions. First, the formalist conception of rule of law would consider whether the programme itself has followed the provisions of the law, particularly the transaction laws. This is often the perspective that the promoters and supporters of privatization resort to when they justify the legality, even the constitutionality of privatization programmes. But, as the

69 Ibid, page 95. See Peoples Union for Democratic Rights v. Minister of Home Affairs (1996) L.R.C (Const), p. 548 where the court suspended procedure constraints and adopted "epistolary procedure" to allow prisoners to litigate on their human rights through letters addressed to the court.

70 Federal Republic of Nigeria $v$. Anache (2004) 14 WRN 1. 
analysis has shown, this claim is undercut by the several failures of the managers to comply with the formalities of legality. The second critique is the substantive justice critique, which, in the context of the papers, focuses on the fundamental objectives and directive principles of state policy in chapter 2 of the Constitution. More specifically, section 16 thereof. The rest of the article will adumbrate on the substantive justice critique in highlighting some of the failures of privatization in Nigeria.

The fact that the privatization process has passed through many phases since its introduction in the late 1980s may give the impression of evident success. Although there have been some successes in the process and improvement in the post-privatization performance of some of the erstwhile public enterprises, the Nigerian model cannot be described as a successful model of privatization. The privatization agency and government spokespersons have boasted of tremendous success with the process. ${ }^{71}$ These exaggerated claims are often based on revenues derived from privatization and token stimulation in the volume of trade or business activities in specific sectors. Much of the assessment has been based on the price of the assets in mind and success has been largely determined by the conclusion of transfer rather than performance improvement in the privatized entity after privatization. ${ }^{72}$

The most successful privatization pointed out by its managers is the liberalization of the telecom sector that improves drastically Nigeria's mobile telephone usage. Although the process involved more of liberalization than privatization, it must be conceded that the involvement of private firms in telecom operations has greatly enhanced telecommunication in Nigeria. Nevertheless, there is such a huge failure in the quality of telecom services provided in Nigeria that questions the claim of success. For example, Nigeria has one of the most expensive

71 Andrew Ojiezel, "BPE Justifies Privatization of PHCN", Vanguard, 28 September 2015 <http://allcitynews.com.ng/bpe-justifies-privatization-of-phcn/> accessed 14 November 2017.

72 This is the trade-off between revenue and efficiency as the motivation for privatization. Where the motivation is to reduce public sector borrowing requirement or to raise revenue for other strategic purposes the state may not care enough about efficiency gains post privatization but care more about revenue grossed from divestment. In that case "auction" may be the best privatization methodology. See Bernardo Bortolotti and Domenico Siniscalco, The Challenges of Privatization: An International Analysis (supra), pp. 16-17. 
calls and the highest frequency of drop-calls in the world. ${ }^{73}$ And these post-liberalization problems in the telecom sector derive from lack of commitment to equity and social justice issues in privatization. All these are secured by paying serious attention to the "regulatory imperative" in section 16 of the Constitution.

The latest efforts at privatization have been in the electricity sector. Here the success story is that by November 2013 the Nigerian government successfully sold 17 companies from the former Power Holding Company of Nigeria (PHCN) to private firms that paid over N400 billion. ${ }^{74}$ These companies include six generating companies and eleven distribution companies. As part of privatization, the government handed management of the Transmission Company of Nigeria (TCN) to a private firm - Manitoba of Canada. Since the privatization of electricity companies, however, services have not improved. The major reasons articulated for privatizing public enterprises in the electricity sector were to improve efficiency measured in terms of availability, reliability and affordability of electricity services and to reduce public sector borrowing requirement for the power sector. ${ }^{75}$ Privatization is expected to increase generation capacity and boost the supply of electricity to Nigerian homes and businesses in the short to medium terms. But the evidence after over a decade of implementation of the reform agenda does not justify the huge sum spent on the reform process. The privatized generation companies have not significantly expanded their capacity since privatization. ${ }^{76}$ Moreover, instead of refusing to spend on any of the sector, as advertised by privatization, government continues to invest billions into the ailing industry. ${ }^{77}$

73 Nigerian Communication Commission, Nigerian Consumer Satisfaction Survey Final Report (Final Report Part 2: Data Analysis, November 2012), pp. 39-40.

74 Clara Nwachukwu, "Nigeria realized N400bn from electricity privatization", Vanguard 3 September 2013< https://www.vanguardngr.com/2013/09/ nigeria-realised-n400bn-from-electricity-privatisation/ $>$ accessed 14 November 2017.

75 National Council on Privatization, the National Electric Power Policy (NEPP) 2000.

76 In 2017, the average daily generation of electricity was $3,687 \mathrm{mw}$ as reported by the system operator < https://www.vanguardngr.com/2017/04/electricitygeneration-averages-3687mw-q117-nbs/> accessed 15 November 2017.

77 The latest financial support from the federal government to the privatized electricity firms is N701bn intervention fund < https://www.thisdaylive.com/ index.php/2017/05/28/n701bn-stimulus-fg-moves-to-buoy-electricitygeneration/> accessed on 15 November 2017. 
Similarly, the quality of service has not improved as customers continue to suffer overbilling because of lack of metering. The level of aggregate technical, commercial and collection (ATC\&C) losses remain as high as it was before privatization. ${ }^{78}$ This data is significant because the distribution companies were sold on the grounds that the private investors would immediately improve the network through strategic financial and technical investment and change management strategies.

The verdict of the Nigerian political authority is that privatization of the electricity sector has failed to achieve its advertised goals or at least has not improved quality of service significantly. ${ }^{79}$ This verdict is not unexpected, given that privatization is rarely successful without a much more sustained social and economic reform. The Nigerian example has been a matter of hurried privatization and shock therapy based on the presumption that the transfer of ownership from public to private sector would automatically result in more efficient and competitive electricity market. This sort of market fundamentalism is rife in developing countries. It leads to the oversight of critical institutional reforms that should accompany privatization.

This is a failure of the rule of law in the design and execution of privatization. Chapter 2 of the Constitution presents some imperatives that would have led to better outcomes. The first imperative is the economic growth imperative. Section 16 mandates the government to manage the economy in a manner that ensures growth. How does privatization contribute to economic growth? One of the arguments in support of this is that it will ensure the efficient allocation of resources, which will boost productivity. In the specific case of the Nigerian economy, the absence of reliable electricity has stunted economic growth. And it is known generally that infrastructure deficit costs huge financial losses to the economy.

But economic growth is not enough to justify privatization and the methodology used. Does the growth translate to social justice? How does the growth in the economy benefit the worst-off? This is the second imperative of the rule of law critique, namely, the social justice imperative. Growth exponents argue as if economic growth automatically

78 Simon Echewofon Sunday, "DisCos loss 40\% of revenue, power in 2016NERC" < https://dailytrust.com.ng/discos-lost-40-of-revenue-power-in-2016nerc.html > accessed on 15 November 2017.

79 Senator Bukola Saraki, "Power Privatization has Failed", Punch, 10 January 2017. 
benefits the poor. As Ke-young Che puts it, "Countries reduce poverty by achieving economic growth. This is how the Western world and, more recently, Japan and newly industrialized countries have reduced poverty" ${ }^{80}$ From this premise, a commitment to economic growth is derivatively a commitment to poverty reduction, which is one way of achieving social justice. But, growth does not necessarily lead to poverty reduction, and the Nigerian example has proved that. The sort of growth that could lead to improved welfare for the poor would be of a particular character. Ke-young Che rightly concedes that the growth that would lead to poverty reduction must be such that is complemented by economic and political institutions that allow the poor to access much of the fruit of economic growth. These institutions, as defined by Douglas North, are humanely devised rules and processes that constrain or enable actions of economic and social actors. ${ }^{81}$

To satisfy the social justice imperative, a privatization programme must be executed in a manner that builds institutions of equity and access to resources. Such institutions will comprise the regulatory landscape of post-privatization. It will also be determined by the methodology adopted for divestment of public shares in the stateowned enterprises (SOEs). One such important institution of equity would be the social safety net. It is important to note that as inefficient as the public enterprises may be, they perform the important function of acting as a social safety net and platform for income redistribution, which are components of a social justice system. ${ }^{82}$ Privatization denies the economic system of this viable instrument of redistribution, thereby compromising efforts at reducing inequality and promoting social welfare.

This latter point goes to the issue of mode of privatization. The preferred mode should be dictated by the preferred outcome. In the context of the fundamental directive of state principle, the preferred outcome should be one that guarantees social security for the poor

80 Ke-young Che, "Collective values, behavioural norms and rules: Building institutions for economic growth and poverty reduction" in Ralph van der Hoeven and Anthony Shorricks (eds.), Perspectives on Growth and Poverty (United Nations University Press 2003), p. 1.

81 Douglas North, Institutions, Institutional Change and Economic Performance (Cambridge University Press, 1990).

82 See the second principle of justice as fairness as articulated by John Rawls in his A Theory of Justice, Ibid. 
people. It should be one that disperses, rather than concentrates wealth. The BPE has often preferred to divest fully to a few investors. But, as Bortolotti and Siniscalco counsel, such a move may guarantee that more money is realized from the sale, but it would also mean that "government loses a powerful instrument for targeted distribution... the right of having representatives on the board in order to affect corporate decisions, and the power to safeguard public interest and national security". ${ }^{83}$

The third imperative, the regulatory imperative, flows from the social justice imperative. The Constitution requires that the economy be regulated in a manner that can guarantee equality and social welfare for all citizens. This means that if the government will hand over public enterprises that play social security and redistribution functions it must ensure that it establishes a strong regulatory regime. In the initial stages of privatization, the government proceeded without the benefits of regulatory regimes, including competition law. The immediate result of this was the failure to improve quality of service even after privatization. In the case of electricity, the privatization happened after the regulatory agency - Nigerian Electricity Regulatory Commission had been established. ${ }^{84}$ Although the regulatory agency had been in existence for about 8 years before the electricity assets were privatized, yet the regulatory regime has not become robust. During the 8 years of its existence of the commission, the Commissioners were sacked from office and absent for about 3-4 years. The new Commissioners appointed in 2010 have barely settled in office when privatization of the electricity sector commenced in earnest.

It was in this milieu of inadequate regulatory experience and capacity that privatization was completed in 2013 without the completion of some of the critical components of a solid regulatory regime. One of such important components is the Power Consumer Assistance Fund (PCAF), which the Electric Power Sector Reform (EPSR) Act requires as a transitional safeguard for poor electricity consumers

83 Bernardo Bortolotti and Domenico Siniscalco supra page 84. It ought to be noted that while privatizing electricity distribution companies, the BPE inserted the right to have a nominal representation on the board.

84 The Nigerian Electricity Regulatory Commission (NERC) was established by sections 31 and 32 of the Electric Power Sector Reform Act 2005 as a commission vested with technical, commercial and social regulation over the electricity supply industry in Nigeria. 
during the initial period of high tariff after privatization. ${ }^{85}$ PCAF is a form of cross-subsidy for poor consumers in order to ensure that during the inevitable initial period of higher tariff there will be no exclusion of access for some citizens. Universal access is a core obligation of the electricity industry as well as a mandate of the Constitution.

Social justice will be violated if citizens are prevented from accessing an essential social service like electricity on account of their inability to pay a high bill. This is compounded in the Nigerian case by the absence of metering. The metering level before privatization was about 40 per cent, and it has remained largely so since privatization. Ordinarily, the metering of customers should have been perfected to guarantee efficient electricity supply long before the introduction of privatization. After failing to provide meters for many customers, or because of it, the operators then proceeded to slam estimated bills on them as a way of recouping collection losses from non-paying customers. This compounds the financial non-viability of the entire electricity value-chains and also weakens the willingness to pay.

These problems and many more reinforce the need for the fourth imperatives of the rule of law: the planning imperative. The Constitution mandates the government to plan the economy in such a manner that will engender prosperity and social justice for all. The imperative of a planned economy requires the government not to abandon a strategic sector like the electricity industry to the uncertainties of a free market. Government ought to design a strategic plan for the working of every aspect of the economy and take responsibility for outcomes instead of placing its hope on the benevolence of the free market.

\section{CONCLUSION}

Generally, Nigeria took the right step in embracing privatization as the preferred economic model to grow its economy and ensure efficient supply of essential services. Although the resort to privatization and other forms of liberalization may have been procured at the instance of the international multilateral financial institutions like the World Bank and the International Monetary Fund (IMF) and its ideology of market fundamentalism, it is still comparatively a wise policy choice to deal with the pervasive inefficiency and corruption of public

85 Section 83 of the Electric Power Sector Reform (EPSR) Act 2005. 
enterprises. But this argument does not extend to accepting the manner in which an acceptable or tolerable policy was executed. While the adoption of privatization as an economic reform policy is compatible with the obligation to enforce and promote the Fundamental Objectives and Directive Principles of State Policy in section 13 of the Constitution, the manner of implementation may not be so compatible. This is what this article has demonstrated.

Section 16 of chapter 2 of the Constitution provides a framework to ensure that privatization achieves the strategic goal of improving efficiency and achieving economic growth. But the the framework also seeks to ensure compliance with the rule of law. Both supporters and critics of privatization fail to highlight this convergence. Rule of law compliance is not just a legalistic concept; it is a commitment that will enable privatization to achieve its strategic goals. The rule of law compliance that will lead to achieving the strategic goals of privatization must go beyond the formal conception of rule of law as compliance with formal criteria of law, namely, generality, certainty, and clarity. It must br built on a substantive justice conception of the rule of law, which requires compliance with a programme that promotes economic and social justice. 